\title{
Ethics Of Tax Law Compliance: An Interdisciplinary Perspective
}

Richard G. Cummings, PhD, CPA, University of Wisconsin-Whitewater, USA

Peter J. Longo, PhD, University of Nebraska at Kearney, USA

Jean W. Rioux, Ph.D., Benedictine College, USA

\begin{abstract}
The first semester Tax I student seems to be interested in the ethical issue of why citizens should report their income and only take legitimate tax deductions when it is unlikely that anyone will ever know. This paper addresses this issue from an interdisciplinary approach of accounting, philosophy, and political science. The accounting perspective discusses the issue from the expectations of the tax preparer and the Internal Revenue Service (IRS). The philosophical perspectives provides background of a citizen who might want to "do the right thing" for the sake of the common good. The political science perspective explores the political nature of the individual and corporate citizen and their approach to civic virtue.
\end{abstract}

Keywords: Accounting Ethics; Civic Virtue

\section{INTRODUCTION}

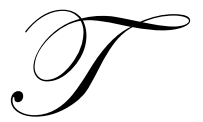

he idea for this paper comes from a question that seems to be asked every semester in tax accounting classes. The question surfaces after students become aware of the Internal Revenue Code (IRC) expectation that taxpayers, when preparing their annual individual tax return, voluntarily report all of their income and only reduce their taxable income by those deductions allowed by the IRC. The question a student will typically ask is, "How would anyone ever know if you report all of your income and take legitimate deductions?" This paper will discuss a specific response to the student question. Yet more importantly, the ethical dimension of tax law compliance will be examined using an interdisciplinary approach from the disciplines of accounting, philosophy, and political science.

The following three individual taxpayers' relatively current situation, as discussed in the current media, provides a perspective about taxpayers' attitude about complying with tax laws.

Joseph Stack, III, albeit the extreme example, took off in a plane on February 18, 2010, and crashed it into an IRS office building (outside of Austin, Texas) that housed close to 190 IRS employees leaving a suicide note detailing his tax issues along with the statement, "Well, Mr. Big Brother I.R.S. man, let's try something different, take my pound of flesh and sleep well." (Brick 2010).

Timothy Geithner, the current United States Secretary of the Treasury who is responsible for the Internal Revenue Service (IRS) which collects taxes for the country had some tax issues discovered during his Senate confirmation hearing in 2009. It appears that while working for the International Monetary Fund (IMF) Mr. Geithner did not pay social security tax on his self-employment income for four years (2001-2004). He did eventually pay over \$ 43,000 in taxes, interest, and penalty for this tax issue. It was unclear why Mr. Geithner did not pay the taxes in light of IMF documents which advised him of this tax liability. Senators on both sides of the aisle identified this as a serious issue but one that should not disqualify him for the Treasury Department's top position (Weisman 2009).

Wesley Snipes, a well known movie actor, is currently serving a three year prison term on his 2008 conviction of failing to file several years of tax returns in which he reportedly owed $\$ 2.7$ million in back taxes 
(Chaney 2010). Snipes began serving his time in December, 2010 has subsequently lost an appeal to the Federal Appeals Court in Atlanta, while the Federal Supreme Court decided not to hear his appeal (Hudak 2011).

In 2009, The Department of the Treasury issued a report entitled the, Update on Reducing the Federal Tax Gap and Improving Voluntary Compliance. In this report based on data collected in 2001 and prior years the Treasury Department reports that the overall compliance rate $84 \%$. Non compliance has created a tax gap (taxes owed but not collected) of $\$ 345$ billion dollars. Individual income tax reporting represents more than $50 \%$ of the total tax gap.

This report identifies that the tax gap is primarily due to the following three criteria:

- Underreporting -- $82 \%$ of gross tax gap (not reporting one's full tax liability on a timely-filed return);

- Underpayment -- $10 \%$ of gross tax gap (not timely paying the full amount of tax reported on a timely-filed return); and

- $\quad$ Nonfiling -- 8\% of gross tax gap (not filing required returns on time and not paying the full amount of tax that should have been shown on the required return).

The majority of this report identifies strategies the Treasury Department is implementing to collect more tax revenue and reduce the tax gap. January, 2011 will find brokerage houses and debit and credit card companies now reporting information to the Treasury Department that will provide more avenues for tax collection.

Measures mentioned above such as more information reporting, and other IRS audit strategies will increase the likelihood of the government identifying taxable income. Thus partially answering the tax accounting student's question of who would ever know if a taxpayer complies with tax laws when filing their individual return. Perhaps the student's question begs a larger issue - especially given the current media coverage-- of what is the right thing to do when filing an individual tax return and complying with tax law. The rest of this paper will discuss this question from the interdisciplinary perspective of accounting, philosophy, and political science.

\section{ACCOUNTING PERSPECTIVE}

The perspective from the accounting area will cover two different domains. First, what is the professional expectation of individuals who prepare tax returns? Second, what is the expectation of the Internal Revenue Service for individuals who file returns and preparers who prepare them?

\section{Professional Expectation}

American Institute of Certified Public Accountants (AICPA)

The American Institute of Certified Public Accountants (AICPA) is the national group of over 350,000 Certified Public Accountants (CPA) who practice accounting in the United States. Members of this group have a college degree, have passed a licensing exam administered by their State Board of Accountancy, have accounting experience, and have passed a Professional Ethics Exam in order to obtain a permit to practice from their state which allows them to hold themselves out as a CPA.

Part of the AICPA Code of Professional Conduct - Principles of Professional Conduct, Section 54 - Article III: Integrity specifically highlights the issue of integrity as:

To maintain and broaden public confidence, members should perform all professional responsibilities with the highest sense of integrity.

.01- Integrity is an element of character fundamental to professional recognition. It is the quality from which the public trust derives and the benchmark against which a member must ultimately test all decisions.

.02 - Integrity requires a member to be, among other things, honest and candid within the constraints of client confidentiality. Service and the public trust should not be subordinated to personal gain an advantage. Integrity can accommodate the inadvertent error and the honest difference of opinion; it cannot accommodate deceit or subordination of principle. 
.03 - Integrity is measured in terms of what is right and just. In the absence of specific rules, standards, or guidance, or in the face of conflicting opinions, a member should test decisions and deeds by asking: "Am I doing what a person of integrity would do? Have I retained my integrity?" Integrity requires a member to observe both the form and the spirit of technical and ethical standards; circumvention of those standards constitutes subordination of judgment.

.04 - Integrity also requires a member to observe the principles of objectivity and independence and of due care.

This section of professional ethics for CPA members suggests that integrity of its members is not only important for the individual but also for the entire profession. The integrity of all members of the AICPA will determine the public confidence and trust in accounting profession.

The AICPA also has specific expectations for those members that provide tax services to clients. The "Statements on Standards for Tax Services", recently reissued in January, 2010, are an enforceable part of the AICPA Code of Professional Conduct. Specific content area listed below by statement includes:

1. Tax Return Positions

2. Answers to Questions on Returns

3. Certain Procedural Aspects of Preparing Returns

4. Use of Estimates

5. Departure From a Position Previously Concluded in an Administrative Proceeding or Court Decision

6. Knowledge of Error: Return Preparation and Administrative Proceedings

7. Form and Content of Advice to Taxpayers

\section{Internal Revenue Service (IRS)}

In a recent Internal Revenue Service (IRS) press release (IR-2010-1, Jan. 4, 2010), IRS Commissioner, Doug Shulman announced new guidelines that "represent a monumental shift in the way the IRS will oversee tax preparers. Our proposals will help ensure taxpayers receive competent, ethical service from qualified professionals and strengthen the integrity of the nation's tax system." The IRS recently completed a Return Preparer Review (begun in June, 2009) which provides new guidelines for the close to 1.2 million tax preparers in the United States. As a result of this review, The IRS recommends the following guidelines for future filing seasons:

- $\quad$ Requiring all paid tax return preparers who must sign a federal tax return to register with the IRS and obtain a preparer tax identification number (PTIN). These preparers will be subject to a limited tax compliance check to ensure they have filed federal personal, employment and business tax returns and that the tax due on those returns has been paid.

- $\quad$ Requiring competency tests for all paid tax return preparers except attorneys, certified public accountants (CPAs) and enrolled agents who are active and in good standing with their respective licensing agencies.

- $\quad$ Requiring ongoing continuing professional education for all paid tax return preparers except attorneys, CPAs, enrolled agents and others who are already subject to continuing education requirements.

- $\quad$ Extending the ethical rules found in Treasury Department Circular 230 -- which currently only apply to attorneys, CPAs and enrolled agents who practice before the IRS -- to all paid preparers. This expansion would allow the IRS to suspend or otherwise discipline tax return preparers who engage in unethical or disreputable conduct.

This shift of greater expectation and guidelines by Commissioner Shulman is indeed monumental. Currently, anyone in the United States can prepare a tax return for someone else and charge a fee. A current effort by the IRS to begin the communication with preparers and visiting problem preparers is a step in the right direction. Extending the ethical rules of Circular 230 standards, which now only apply to attorneys, CPAs and enrolled agents can do much to improve the integrity of the country's federal tax collection system. 


\section{PHILOSOPHICAL PERSPECTIVE}

law?

What are citizens' ethical obligations concerning filing an individual tax return and complying with tax

\section{Utilitarianism}

The overwhelmingly predominant model for determining our ethical obligations in the social realm is utilitarianism. Governed by a principle variously-named "the greatest happiness principle" (Mill: II-III) or "enlightened self-interest", utilitarianism applies a method of determining what manner of social or private action will contribute to the greatest happiness for all, and favors the imposition of sanctions upon those who choose not to act accordingly.

A key question under this model includes why should an individual pursue the greatest happiness for the greatest number rather than their own personal happiness?

Each citizen could be directed to pursue that course of action which, by his or her own, or perhaps a common, estimation would further the economic good of as many as possible. This would mean filing a tax form and paying taxes in line with the laws only if this action in fact did lead to the greatest happiness for the greatest number. He or she might avoid such an action if a lesser happiness arguably would come about. This calculation would occur each time one was called upon to file and pay taxes. The completed process might require one or more actions in line with tax laws, yet not require some others, and may even end up forbidding one or more. Each citizen could be expected to comply with general rules of action which have been seen to lead to the greatest social happiness.

\section{Deontology}

Based upon a non-empirical and a priori (logical) method of evaluating the rightness of actions, deontology would favor establishing codes of conduct which do not admit of exception in the first place. The application of deontological principles to the question of tax compliance would tend not to raise the same questions as with utilitarianism, since deontologists do not proceed inductively. Unlike the utilitarian, changes among the circumstances of human action would not warrant making changes to the general rules themselves or excepting individual actions (categorical imperative). Initially establishing tax law compliance or non-compliance as a duty using logic alone would constitute the bulk of the deontologist's concern with the question. The question of treating persons as means or ends (Kant) would also enter in.

\section{Natural law-based virtue ethics}

Mid-way between deontology and utilitarianism stands a natural law-based virtue ethics (Aristotle I-II, V 7, Thomas Aquinas I-II 90-97). Beginning with principles grounded in the empirical world of the utilitarian, virtue ethics also draws from the natures it discovers there logical implications for human action, some of which are arguably categorical.

Questions which arise for this middle position include:

- Is there a natural relation between the individual and society upon which (especially) positive and (of less importance here) negative obligations can be based?

- Does the application of any such obligations occur at the more general or the more specific level (the obligation to file and pay taxes being a very specific and positive one)?

- What measures can be taken (whether personally or socially) to decide whether my filing and compliance with tax laws is both equitable and fair?

A citizens' ethical obligations concerning filing an individual tax return and complying with tax law is informed by the models of utilitarianism, deontology, and natural law. Yet the important issue is to address the 
origin and basis of the rules imposed upon themselves (the expectations of the AICPA) and others (IRS guidelines and enforceable rules for all tax preparers) by those who can do so. It is one sort of answer to suggest that "because they're getting better at tracking and punishing non-compliance", then a citizen should take their individual tax liability seriously and quite another to say "because it is the right thing, the consequences notwithstanding". Natural law seems to provide a clear case for paying your taxes because it is the right thing to do.

The case from natural law avoids the contingency of a utilitarian assessment (natural law would say, given human nature, that for the sake of the common good we conclude that it's right and fair to pay taxes, and governments are right in expecting that we do). Utilitarianism could only conclude this on the basis of concrete circumstances under which the greatest happiness happened to be the direct result of paying taxes; it could very well turn out otherwise.

Natural law also avoids the inability of deontology (which would tell you to "just shut up and pay your taxes") to accommodate situations giving rise to the concrete reality of the ethical life. This answer, in the abstract, may be one thing, but in the concrete quite another.

For example, the logical extreme case arising from a "peace tax" proposal (where the taxpayer can designate that their taxes cannot be used for military purposes) is not paying taxes at all, as it is possible that others will want their own strongly-held beliefs accommodated in a fashion similar to the "peace tax": a "life tax" (for those opposed to using taxes to fund abortions and other acts against human life), an "inclusive" tax (for those opposed to using tax monies to foster divisions in society, such as actions against illegal immigrants), and so on; it is logically possible, then, that a government may arise to which one may object as a whole - not paying taxes at all would, in that case, be the justified (and ethical) result.

\section{POLITICAL SCIENCE PERSPECTIVE}

The politics regarding tax is but one of many substantive policy issues that confounds lawmakers and citizens alike. Assorted tax legislation--- federal, state, and local--- is complicated and often unintelligible to the typical citizen. The legislative directives allow citizens, individual and corporate, a wide array of responses. From a political science and policy perspective, Sheldon Pollack aptly describes the overall tax process as follows:

Tax policy is made through a dynamic process reflecting the interplay of many different economic and political interests. These interests and institutions compete for control or influence over the policymaking process within Congress and its committees. This includes the president, the national political parties, special interest groups, individual congressmen, tax experts and professionals from within the legislative and executive branches, public interest groups, policy promoters from Washington think tanks, as well as the journalists who report on politics and legislative events. In the struggle for influence over tax policy, the ultimate goal is to shape the outcomes of the legislative process, and the first step in exerting such influence is to control what is on the political agenda (1995:69)

The complexity of tax policy and politics leaves many a citizen in a muddled quandary. The legislation guides some citizens to pay taxes, some citizens to seek exemptions, and some citizens to avoid taxes altogether. When citizens claim a tax is not fair, the final arbitrator, the judiciary, is reluctant to change legislative policy. Thus the political process that created legislation seems to create three different scenarios: 1) law abiding citizens will pay their fair share of taxes; 2) Some taxpaying citizens will seek "loopholes" in the tax code; and 3) some citizens will ignore all tax compliance.

Tax time brings out the creative flair for many a citizen as the search for loopholes is a standard practice. Yet, not all citizens are given a passing mark in creativity. As stated in an insightful 1941 tax opinion: "The two petitioners wished to reduce their income taxes. This desire is shared by many of their fellow citizens, rich or poor, and therefore is so far, so good. The Government contends, however, that too far is not so good and says that here the taxpayers employed a device that did go too far, in the legal sense at any rate. They went down a road which has not been marked by any very satisfactory judicial 'dangerous curve ahead' signs. The relation (or lack of it) between ethics and tax avoidance (evasion) has puzzled judges and others who have considered the subject." (DuPont $v$. 
Internal Revenue Commissioner, 118 F.2d 544) The tax road often presents obstacles to the governed and governing.

The politics of enforcement deserves considerable attention. The economy often drives politics and the economic realities of tax enforcement cannot be ignored. As noted by Leviner: "Empirical and experimental studies tend to support the economic model of compliance to the extent that they generally identify a negative relationship between the probability and severity of punishment and the rate of crime. In other words, an increase in either the probability or the severity of punishment can change the expected utility of noncompliance from positive to negative, thereby deterring potential offenders and, overall, decreasing the level of crime. This effect has also been identified in the area of tax compliance. The correlation between increased enforcement and compliance appears to be stronger, however, when the probability of detection is increased than when the punishment is made more severe. In either case, enforcement efforts relying exclusively on punitive strategies do not always alleviate the problem of noncompliance and, at times, might even worsen the situation" (2009: 400). Lawmakers must go beyond the reliance of goodwill for compliance certainty and reinforce goodwill with meaningful enforcement tactics.

Tax resisters who are moved by morality or ethics also find little comfort in the tax politics milieu. Tax protests, no matter how nobly motivated by just political causes, are viewed universally in an unfavorable light as commented by Kornhauser: "The government is correct in treating seriously people who do not pay their taxes, especially those who deliberately refuse to pay their taxes as a means of protesting against the government. This does not mean, however, that its manner of treatment is correct. Currently the government treats all tax protesters identically even though their reasons for protesting differ greatly." (1999:942).

While the passage underscores the essential political need to collect taxes, Kornhauser offers a policy alternative for lawmakers. Kornhauser calls for new legislation to capture a peace tax: "War tax resisters refuse to pay all or a portion of their income taxes because a large portion of their taxes supports the military. Their conscientious objection to war is part of a long and respected tradition in the United States. This refusal to pay taxes exacts a high price from the resisters and from the government. The resisters sacrifice money (interest and penalties), possessions (when levies are necessary), and peace of mind (anxiety about the collection process and the conflict between their conscience and their legal duty to pay taxes). The price for the government is also high. It loses some revenue as well as the respect of some of its citizens. Additionally, the IRS has increased compliance costs. This lose-lose situation is unnecessary, however. Most war tax resisters would willingly pay their taxes if they could do it without violating their consciences. A peace tax fund would allow them to do so because none of their tax monies would be used for military purposes. Such a fund would decrease compliance costs, increase revenues (even if only marginally), and help restore respect for the IRS and the tax system. Contrary to the Treasury's concerns, a peace tax fund would not create undue administrative burdens on the IRS, nor would it open the floodgates to other taxpayers claiming the right to specify where their tax dollars should go. A peace tax fund, therefore, would turn a lose-lose situation into a win-win situation" (1999:1015). The political landscape could change dramatically if Congress and other lawmakers strategically legislated in a manner described above. No doubt there could be a variety of equitable plans formulated to capture revenues and the interest of more citizens.

Citizens reacting to so-called "bad legislation" can find little comfort in a judicial challenge to such alleged legislation. For example, the United States Tax Court in Pollock v. Internal Revenue Commissioner (132 T.C. 21; 2009 U.S. Tax Ct. LEXIS 3; 132 T.C. No. 32009) illustrates the reluctance of the judiciary to impose judicially crafted equity. Precisely the court offered: "This leads us to an important question -- how flexible we can be in construing to provide her with a forum for her case under these unusual circumstances?[W]e lack general equitable powers to expand our statutorily prescribed jurisdiction And though we can apply equitable principles to decide a case over which we do have jurisdiction, our inability to apply those principles to expand our jurisdiction to cases where we otherwise wouldn't have it is really nothing more than a fancy way of saying we can't override statutory limits on our power. We are similarly reticent in our refusal to create deductions, credits, or exclusions out of a desire for a fairer outcome -- we understand that this would be legislation, and legislation belongs exclusively to Congress."

As legislation and case law continues to unfold, the moral challenges for a citizen to exercise civic virtue remains constant in the political world. Lawrence Zelenak examined the tax complexities and civic virtue and offers the following astute observations: 
Given the overwhelming complexity of the income tax return preparation process today, it is difficult to imagine (or remember) that a tax filing obligation might have civic virtues. A system of inexact withholding and return-based reconciliation can serve as an attractive compromise between small government proponents who would like to make the taxpaying process as visible and painful as possible and big government proponents who would like to make the process invisible and painless. And if the tax system is not so complicated as to make return preparation a miserable experience (in terms of the taxpayer's own time and effort, money paid to a preparer, or both), the return preparation and filing process can serve as civic ceremony of equal dignity and importance to voting. All these benefits would be lost under a national sales tax or value-added tax, or under an income tax with exact withholding and no return filing (2007: 87-88).

Even in the heated partisan political milieu what should not be lost is the need for tax simplification. Such simplification ought to reduce the heated partisan exchanges and provide common ground for civic virtue. Tax reform should start with the common ground and not partisan electoral advantage.

\section{CONCLUSION}

Addressing civic virtue with tax reform could bring business, philosophy, and political science together. Certainly, the political path of tax policy could benefit from reform. Such reform should consider sound business principles as well as ethical dimensions. The politics of the status quo is less than satisfying. Surely, lawmakers in search of the common good can formulate tax policies that will improve the political community of all citizens.

\section{AUTHOR INFORMATION}

Dr. Cummings is an associate professor of Accounting at the University of Wisconsin-Whitewater. He teaches individual taxation and MBA- Financial Accounting. His research interests include: empirical studies in horizontal equity in individual taxation, the effect of Subchapter $\mathrm{S}$ election in community banks, international accounting, and accounting education. E-mail: cummingr@uww.edu. Corresponding author.

Dr. Peter Longo has been at the University of Nebraska at Kearney since 1988. He is the co-author of a Nebraska Constitution book and a co-editor of a Great Plains water book as well as the author or co-author of several articles and chapters. He served on the Nebraska Constitutional Revision Commission and currently serves on the Nebraska State Advisory Committee to the U.S. Commission on Civil Rights.

Dr. Rioux is a professor and chair of Philosophy at Benedictine College. He teaches a range of courses, from epistemology to ethics to metaphysics. His professional and research interests include 3D courseware development, philosophy of mathematics and natural philosophy, and the great books.

\section{REFERENCES}

1. Aquinas, Thomas. (1947) Summa Theologica. (Fathers of the English Dominican Province, Trans.). New York: Benziger.

2. Aristotle. (1941) Nicomachean Ethics. (Ross, W.D., Trans.). Richard McKeon, (Ed.). New York: Random House, Inc.

3. $\quad$ Brick, M. 2010. Man Crashes Plane into Texas IRS Office. New York Times (February 18).

4. Chaney, J. 2010. Wesley Snipes Dishes about His Tax Woes, New Movie. Washington Post (February 28).

5. Hudak, S. 2011. Supreme Court Won't Hear Appeal of Wesley Snipes on Tax Charges. McClatchy Tribune Business News. Washington: (June 6).

6. Hudak, S. 2011. Actor Wesley Snipes Loses Latest Appeal. McClatchy-Tribune Business News. Washington: (September 6, 2011).

7. Kant, Immanuel. (1993) Grounding for the Metaphysics of Morals. (Ellington, James W., Trans.). Indianapolis, Indiana: Hackett.

8. Kornhauser, Marjorie, E. (1999). For God and Country: Taxing Conscience. Wisconsin Law Review, 1999, 939-1016. 
9. Leviner, Sagit. (2009). A New Era of Tax Enforcement: from a 'Big Stick' to Responsive Regulation. University of Michigan Journal Law Reform. 42, 381- 429.

10. Mill, John Stuart. (2006) Utilitarianism. Steven M. Cahn, (Ed.). Indianapolis, Indiana: Hackett.

11. Pollack, Sheldon D. (1995). New Dynamics of Tax Policy? The American Journal of Tax Policy, 12, 61-99 (1995).

12. Zelenak, Lawrence. (2007). Justice Holmes, Ralph Kramden, and the Virtues of a Tax Return Filing Requirements. Tax Law Review 61, 53-88.

13. 2009. Update on Reducing the Federal Tax Gap and Improving Voluntary Compliance. U.S. Department of the Treasury (July 9).

14. Weisman, J. 2009. Geithner's Tax History Muddles Confirmation. Wall Street Journal (January 14).

15. _ AICPA Code of Professional Conduct - Principles of Professional Conduct, Section 54 - Article III: Integrity, June 1, 2011.

16. — AICPA Statement on Standards for Tax Services. (1-7), January 1, 2010.

17. IRS Proposes New Registration, Testing and Continuing Education Requirements for Tax Return Preparers Not Already Subject to Oversight. IR-2010-1, Jan. 4, 2010. 